\title{
Iwona Kurzawa
}

Uniwersytet Ekonomiczny we Wrocławiu

Wydział Ekonomii, Zarządzania i Turystyki w Jeleniej Górze

e-mail: iwona.kurzawa@ue.wroc.pl

\section{GENERACJA NEET W POLSCE I WYBRANYCH KRAJACH UNII EUROPEJSKIEJ}

\section{NEET GENERATION IN POLAND AND SELECTED COUNTRIES OF THE EUROPEAN UNION}

DOI: $10.15611 /$ pn.2018.529.13

JEL Classification: E24, E62

Streszczenie: W artykule przedstawiono definicję zjawiska NEET, dokonano charakterystyki osób należących do grupy NEET w grupie wiekowej 15-29 oraz jej struktury. Sytuację zjawiska NEET przedstawiono w wybranych krajach Unii Europejskiej, tj. Polsce, Danii, Holandii, Hiszpanii i Grecji, oraz scharakteryzowano koszty ekonomiczne i społeczne związane z wystąpieniem zjawiska NEET. Zakres czasowy badań opartych na danych Europejskiego Urzędu Statystycznego (Eurostat) obejmuje lata 2008-2016. W pierwszej części artykułu dokonano charakterystyki młodych ludzi należących do generacji NEET, w kolejnej przedstawiono wielkość i strukturę generacji NEET, w ostatniej części artykułu określono koszty społeczne i gospodarcze związane z występowaniem zjawiska bezrobocia wśród badanej młodzieży. W zakończeniu przedstawiono wnioski wynikające z przeprowadzonego badania.

Słowa kluczowe: NEET, młodzież, pokolenie.

Summary: The article presents the definition of the NEET generation, characterization of people belonging to the NEET group in the 15-29 age group and the structure of NEET. The situation of NEET was presented in selected European Union countries, in Poland, Denmark, the Netherlands, Spain and Greece, and the economic and social costs related to the occurrence of NEET were characterized. The time range of research based on the data of the European Statistical Office (Eurostat) covers the years 2008-2016 The first part of the article features the characteristics of young people belonging to the NEET generation, the next part presents the size and structure of the NEET generation, in the last part the article specifies social and economic costs related to the occurrence of unemployment among the examined youth. The conclusions are presented in the conclusion from the study.

Keywords: NEET, youth, generation. 


\section{Wstęp}

Bezrobocie wśród młodzieży nie jest nowym zjawiskiem, a w kilku krajach Unii Europejskiej od roku 2008 odnotowuje się wysokie stopy tego rodzaju bezrobocia. Młodzi ludzie są podstawowym zasobem wszystkich gospodarek i społeczeństw, dlatego istotnym wyzwaniem jest sprostanie problemowi bierności zawodowej wśród młodych osób. Szczególnie trudnym zjawiskiem dla poszczególnych krajów Unii Europejskiej jest wysoka stopa bezrobocia oraz bierność zawodowa wśród młodych ludzi należących do generacji NEET.

Osoby należące do generacji NEET często postrzegane są wśród społeczeństwa jako osoby o niskim poczuciu wartości, niskich kwalifikacjach zawodowych, zniechęcone do podejmowania zatrudnienia i o braku poczucia samorealizacji. Z drugiej strony mogą to być osoby posiadające wysokie kwalifikacje zawodowe, które chcą być aktywne zawodowo, ale często dostosowanie ich kwalifikacji do aktualnych ofert na rynku pracy jest trudne do osiągnięcia. W związku z tym można stwierdzić, iż grupa osób składająca się na generację NEET jest niejednorodna.

Celem opracowania jest scharakteryzowanie wielkości i struktury zjawiska NEET w Unii Europejskiej oraz w wybranych krajach, tj. w Polsce, Danii, Holandii, Hiszpanii i Grecji.

\section{Charakterystyka generacji NEET}

Generacja NEET określana jest jako pokolenie trzy razy nic - czyli osoby młode niepracujące, niekształcące się i nieszkolące się (Not in education, employment, or training). Osoby należące do generacji NEET są kimś więcej niż tylko „młodymi bezrobotnymi”, są to również absolwenci bierni zawodowo (niezatrudnieni i nieposzukujący zatrudnienia), osoby, które wcześnie ukończyły edukację i nie weszły na rynek pracy. Dodatkowo nie każdy NEET musi być osobą bezrobotną i nie każda osoba bezrobotna musi należeć do generacji NEET. W praktyce oznaczać to może sytuację, z jaką mamy do czynienia w przypadku studentów studiów niestacjonarnych, którzy mogą być zarejestrowani w urzędzie pracy, ale nie należą do generacji NEET, ponieważ dalej się kształcą.

Po raz pierwszy pojęcie NEET zostało użyte w 1999 roku w brytyjskim raporcie rządowym Bridging the Gap, w kontekście sytuacji młodzieży między 16. a 18. rokiem życia, która przez przynajmniej 6 miesięcy ani się nie uczyła, ani nie pracowała, jak również nie uczestniczyła w jakimkolwiek kursie dokształcającym [Rogozińska-Pawełczyk 2014, s. 112]. W krajach anglosaskich nazywana jest młodzieżą Not in employment, education or training (skąd wzięła swoje nazewnictwo), w krajach hiszpańskojęzycznych generación ni-ni, natomiast w polskim tłumaczeniu oznacza pokolenie ani-ani. We Włoszech oprócz powszechnego pojęcia NEET używa się żartobliwie słowa bamboccioni, czyli „wielkich bobasów”, i odnosi się do młodzieży, która pozostaje z rodzicami nie ze względu na realne wymogi, ale z uwagi na 
konsumpcyjny model życia, nastawiony na zaspokojenie własnych potrzeb przy jak najniższych wydatkach [Rogozińska-Pawełczyk 2014, s. 112].

Z danych dostępnych w Eurostacie wynika, iż w Grecji, Hiszpanii oraz Polsce średni wiek młodzieży opuszczającej dom rodzinny to 28 lat, natomiast w Danii i Holandii to średnio 21-23 lata, czyli o 5-7 lat wcześniej [Eurostat 2018].

Generacja NEET nie jest jednorodną grupą osób, jest to grupa bardzo zróżnicowana. Wśród generacji NEET można wyróżnić następujące podgrupy:

- Osoby bezrobotne,

- Osoby opiekujące się dziećmi lub osobami zależnymi,

- Osoby przewlekle chore lub niepełnosprawne,

- Osoby zniechęcone poszukiwaniem pracy/edukacją,

- Osoby, które poszukują pracy adekwatnej do ich kwalifikacji,

- ,Wolontariusze” - osoby podróżujące lub obecnie zajmujące się np. sztuką.

Przytoczone wyżej czynniki mogą się na siebie nakładać, co może potęgować siłę ich oddziaływania na sytuację osobistą i zawodową młodych ludzi. Oczywisty jest fakt, że żadna z wymienionych wyżej okoliczności nie przekreśla szansy na uzyskanie odpowiedniego wykształcenia oraz znalezienie stałej pracy i nie może być wymówką dla postawy bierności i zniechęcenia [Rogozińska-Pawełczyk 2014, s. 113]. Natomiast młodzi ludzie posiadają różne zasoby (edukacyjne, społeczne), które wpływają na ich możliwości sprostania wymaganiom związanym z integracją globalnych rynków ekonomicznych i dynamicznie zmieniającą się technologią [Olofsson, Panican 2018, s. 80]. Wygodnym wytłumaczeniem dla osób z generacji NEET jest brak chęci do podjęcia pracy poniżej kwalifikacji lub za mniejszą pensję niż pierwotne oczekiwania [Rogozińska-Pawełczyk 2014, s. 113]. Każda typologia pokoleń ma ścisły związek z rynkiem i konsumpcją [Rogozińska-Pawełczyk 2014, s. 114]. W związku z tym obecna generacja NEET oscyluje wśród ludzi z pokolenia Y i Z.

Pokolenie Y jest to pokolenie ludzi urodzonych w latach 1980-2000, czasem nazywane pokoleniem milenijnym lub pokoleniem końca wieku [Suwa 2014, s. 66]. Mentalność osób z pokolenia Y ukształtowana jest przez rewolucję technologiczną. Pozytywnymi cechami osób urodzonych w tym okresie jest dobra znajomość nowych technologii, nastawienie na rozwój osobisty, niezależność oraz współpraca. Niestety oprócz zalet generacja Y posiada także wady, którymi są: egoizm, bunt przed podporządkowaniem się określonym regułom, roszczeniowa postawa wobec pracodawcy itd. Zdaniem J. Fazlagica osoby należące do pokolenia Y miewają nierealistyczne oczekiwania, uważają, że mogą zmienić świat w ciągu pierwszego dnia pracy [Suwa 2014, s. 67].

Osoby z pokolenia Z to osoby urodzone po roku 1990, utożsamiane są z postępem teleinformatycznym, charakteryzują się „multiumiejętnościami”, czyli potrafią robić kilka rzeczy na raz, mają podzielność uwagi, ale to również ludzie, którzy bardzo łatwo ulegają trendom. To ludzie, którzy nie lubią ,zapuścić korzeni w jednym miejscu", są indywidualistami, nawet można rzec, że samotnikami, z drugiej strony są to ludzie kreatywni, ceniący sobie niezależność. Często osoby urodzone w tym 
czasie określa się mianem ,pokolenie C”, od angielskiego słowa connected, z uwagi na ciągły kontakt z mediami społecznościowymi, takimi jak Facebook czy Twitter, za pomocą nieodłącznych telefonów komórkowych [Gałaj 2014, s. 85]. To pokolenie, które żyje na pograniczu realnego i wirtualnego świata, które nie wyobraża sobie życia bez Internetu.

\section{Wielkość i struktura generacji NEET}

W celu monitorowania sytuacji ludzi młodych na rynku pracy, w ramach strategii Europa 2020 oraz do przeprowadzenia porównań międzynarodowych, Komitet Zatrudnienia (EMCO) oraz Dyrekcja Generalna ds. Zatrudnienia, Spraw Społecznych i Włączenia Społecznego (EMPL) przy Komisji Europejskiej w 2010 roku uzgodniły definicję i metodykę standaryzowanego wskaźnika pomiaru populacji NEET wśród państw członkowskich. Przyjęto, że wskaźnik ten obejmuje młodzież w wieku 15-29 lat, bezrobotną lub bierną zawodowo oraz nieuczącą się.

Wskaźnik dotyczący stopy NEET zbudowany jest z licznika i mianownika [Eurofond 2012]:

- Licznik - stanowi liczbę młodych osób w wieku 15-29 lat, które: nie są zatrudnione (w tym również nieaktywne zawodowo) oraz nie otrzymały oferty kształcenia się lub szkolenia w ciągu 4 tygodni poprzedzających badanie.

- Mianownik - stanowi całkowitą liczbę populacji młodych osób w wieku 15-29 bez badanych (ankietowanych), którzy nie odpowiedzieli na pytanie w sprawie udziału w regularnej (formalnej) edukacji i szkoleniach.

Różnica pomiędzy określeniem stopy bezrobocia wśród osób młodych a stopą NEET przedstawiona została na rys. 1.

\begin{tabular}{|c|c|c|}
\hline $\begin{array}{c}\text { Stopa } \\
\text { bezrobocia } \\
\text { osób młodych } \\
\text { Udział liczby } \\
\text { osób młodych } \\
\text { bezrobotnych } \\
\text { w liczbie osób } \\
\text { młodych } \\
\text { aktywnych } \\
\text { zawodowo }\end{array}$ & Bezrobotni szkolący się \\
\cline { 2 - 2 } & Bezrobotni & \\
\hline
\end{tabular}

Rys. 1. Stopa bezrobocia wśród młodych osób a stopa NEET

Źródło: opracowanie własne na podstawie [https://www.eurofound.europa.eu].

Sposób obliczania stopy bezrobocia osób młodych i stopy bezrobocia NEET przedstawia poniższy schemat (źródło: https://www.eurofound.europa.eu). 


\section{Stopa bezrobocia osób młodych}

\section{Liczba bezrobotnych osób młodych \\ $\overline{\text { Liczba osób młodych aktywnych zawodowo }}$ \\ Stopa NEET \\ Liczba osób młodych NEET \\ Liczba populacji młodych ludzi ogółem}

Stopa bezrobocia wśród osób młodych w wieku 15-29 obejmuje tylko aktywnych zawodowo ludzi, natomiast stopa NEET rejestruje udział populacji wszystkich młodych ludzi, którzy obecnie są „odłączeni” od rynku pracy, czyli osoby bezrobotne i nieaktywne zawodowo - nie uczestniczą w kształceniu ani szkoleniu.

$\mathrm{Z}$ danych przedstawionych $\mathrm{w}$ tab. 1 wynika, że największe bezrobocie wśród osób z przedziału wiekowego 15-29 występuje w Grecji i Hiszpanii, najniższe w Holandii i Danii.

Tabela 1. Stopa bezrobocia wśród osób w wieku 15-29 w wybranych krajach Unii Europejskiej w latach 2008-2016 ( w \%)

\begin{tabular}{|l|r|r|r|r|r|r|r|r|r|}
\hline Wyszczególnienie & \multicolumn{1}{c|}{2008} & \multicolumn{1}{c|}{2009} & 2010 & 2011 & 2012 & 2013 & 2014 & 2015 & 2016 \\
\hline Unia Europejska & 11,7 & 15,2 & 16,3 & 16,6 & 17,9 & 18,4 & 17,3 & 15,7 & 14,3 \\
\hline Dania & 5,8 & 10,0 & 12,1 & 12,4 & 12,3 & 11,2 & 10,8 & 9,5 & 10,4 \\
\hline Grecja & 16,8 & 19,2 & 24,8 & 35,4 & 43,7 & 48,6 & 45,0 & 41,5 & 38,3 \\
\hline Hiszpania & 17,4 & 27,3 & 30,9 & 33,6 & 39,4 & 41,4 & 38,9 & 36,1 & 32,7 \\
\hline Holandia & 3,6 & 4,9 & 6,6 & 7,2 & 8,6 & 10,1 & 9,8 & 8,7 & 8,1 \\
\hline Polska & 12,0 & 14,2 & 16,9 & 17,5 & 18,4 & 18,9 & 16,5 & 14,2 & 11,8 \\
\hline
\end{tabular}

Źródło: [http://ec.europa.eu/eurostat/].

Stopa bezrobocia wśród osób w wieku 15-29 dla UE-28 (tab. 1) od 2009 roku była wyższa niż stopa bezrobocia wśród osób z generacji NEET (tab. 2). W Danii największy wzrost stopy NEET nastąpił od 2009 do 2012 i wyniósł w 2012 roku $8,2 \%$. Podobna sytuacja występowała w Holandii, gdzie od 2009 roku stopa NEET kształtowała się na niższym poziomie niż stopa bezrobocia wśród ogólnej liczby młodych ludzi w wieku 15-29. Stopa NEET od 2009 do 2014 roku wzrosła o 2,2 p.p. W Grecji, Hiszpanii i Polsce stopa wśród NEET w badanym okresie była niższa niż stopa bezrobocia wśród młodzieży w wieku 15-29. W Grecji stopa NEET od 2009 do 2013 roku wzrosła o 12,6 p.p., w Hiszpanii o 2,6 p.p., natomiast w Polsce o 2,2. Największy wzrost stopy NEET nastąpił w Grecji. Z przeprowadzonej analizy można również wywnioskować, iż w Polsce w badanym okresie wielkość stopy NEET nie różniła się znacząco od wielkości stopy bezrobocia wśród osób w wieku 15-29, 
można też stwierdzić, iż wśród bezrobotnej młodzieży w wieku 15-29 przeważają osoby z generacji NEET.

Tabela 2. Stopa NEET wśród osób w wieku 15-29 w wybranych krajach Unii Europejskiej w latach 2008-2016 (w \%)

\begin{tabular}{|l|c|r|r|r|r|r|r|r|r|}
\hline Wyszczególnienie & 2008 & 2009 & 2010 & 2011 & 2012 & 2013 & 2014 & 2015 & 2016 \\
\hline Unia Europejska & 13 & 14,7 & 15,2 & 15,4 & 15,9 & 15,9 & 15,4 & 14,8 & 14,2 \\
\hline Dania & 5 & 6,5 & 7,3 & 7,6 & 8,2 & 7,5 & 7,3 & 7,7 & 7,4 \\
\hline Grecja & 14,8 & 15,9 & 18,6 & 23 & 26,8 & 28,5 & 26,7 & 24,1 & 22,2 \\
\hline Hiszpania & 15,3 & 19,9 & 20 & 20,6 & 22,2 & 22,5 & 20,7 & 19,4 & 18,1 \\
\hline Holandia & 4,6 & 5,3 & 5,7 & 5,9 & 6,5 & 7,5 & 7,6 & 6,7 & 6,3 \\
\hline Polska & 12,7 & 14 & 14,8 & 15,2 & 15,7 & 16,2 & 15,5 & 14,6 & 13,8 \\
\hline
\end{tabular}

Źródło: [http://ec.europa.eu/eurostat/].

Europejski rynek pracy w ostatnim dziesięcioleciu przeszedł znaczne przemiany, które związane były z m.in. z kryzysem gospodarczym, zmianami w obszarze oferowanych stanowisk pracy $\mathrm{w}$ związku $\mathrm{z}$ zastosowaniem nowych technologii [Malo, Moreno 2018, s. 1]. Grecja i Hiszpania to kraje, w których skala zmian gospodarczych w latach 2008-2012 była największa. W Grecji głównym powodem problemów gospodarczych po roku 2008 było bardzo wysokie zadłużenie publiczne. Natomiast w Hiszpanii trzykrotny wzrost zadłużenia publicznego po roku 2007 był następstwem m.in. działań ratunkowych sektora prywatnego, zwłaszcza finansowego, i przyjęcia długu prywatnego przez sektor publiczny [Kubin 2016]. Najpoważniejszym skutkiem kryzysu gospodarczego w wymiarze społecznym był wzrost stopy bezrobocia wśród osób młodych w wieku 15-29 oraz stopy bezrobocia wśród generacji NEET.

Stopa bezrobocia wśród mężczyzn w wieku 15-29 w badanym okresie dla całej Unii Europejskiej jest wyższa niż stopa NEET. Również we wszystkich pięciu bada-

Tabela 3. Stopa bezrobocia wśród mężczyzn w wieku 15-29 w wybranych krajach Unii Europejskiej w latach 2008-2016 (w \%)

\begin{tabular}{|l|r|r|r|r|r|r|r|r|r|}
\hline \multicolumn{1}{|c|}{ Wyszczególnienie } & \multicolumn{1}{c|}{2008} & \multicolumn{1}{c|}{2009} & 2010 & 2011 & 2012 & 2013 & 2014 & 2015 & 2016 \\
\hline Unia Europejska & 11,7 & 15,9 & 16,9 & 17,0 & 18,4 & 18,9 & 17,7 & 16,2 & 14,6 \\
\hline Dania & 5,2 & 11,4 & 13,8 & 13,2 & 13,0 & 11,6 & 11,7 & 9,9 & 10,7 \\
\hline Grecja & 13,3 & 15,0 & 20,2 & 30,9 & 39,9 & 44,9 & 42,1 & 37,6 & 33,9 \\
\hline Hiszpania & 17,1 & 28,5 & 32,3 & 35,3 & 41,1 & 42,6 & 39,3 & 36,7 & 32,5 \\
\hline Holandia & 3,5 & 5,3 & 6,9 & 7,4 & 8,5 & 10,5 & 9,7 & 8,9 & 8,5 \\
\hline Polska & 10,7 & 13,6 & 16,2 & 16,0 & 16,5 & 17,4 & 15,8 & 14,5 & 11,7 \\
\hline
\end{tabular}

Źródło: [http://ec.europa.eu/eurostat/]. 
nych krajach stopa NEET w latach 2008-2016 jest niższa niż stopa bezrobocia wśród mężczyzn w wieku 15-29 dla tych krajów. Największy wzrost stopy NEET w latach 2009-2013 nastąpił w Grecji - o 14,3 p.p.

Jak można zauważyć, analizując dane w tabele 5 i 6 , stopa bezrobocia wśród kobiet w wieku 15-29 w badanym okresie dla całej Unii Europejskiej jest wyższa niż stopa NEET. Również we wszystkich pięciu badanych krajach stopa NEET w latach 2008-2016 jest niższa niż stopa bezrobocia wśród kobiet w wieku 15-29 dla tych krajów. Największy wzrost stopy NEET w latach 2009-2013 nastąpił także w Grecji - o 11,4 p.p. (był niższy niż w przypadku stopy NEET dla mężczyzn).

Tabela 4. Stopa NEET - bezrobotni mężczyźni w wieku 15-29 lat w wybranych krajach Unii Europejskiej w latach 2008-2016 (w \%)

\begin{tabular}{|l|c|r|r|r|r|r|r|r|r|}
\hline \multicolumn{1}{|c|}{ Wyszczególnienie } & 2008 & 2009 & 2010 & 2011 & 2012 & 2013 & 2014 & 2015 & 2016 \\
\hline Unia Europejska & 5,9 & 8,1 & 8,4 & 8,3 & 8,9 & 9,0 & 8,4 & 7,7 & 6,9 \\
\hline Dania & 2,1 & 3,9 & 4,4 & 3,6 & 3,7 & 3,0 & 3,1 & 3,1 & 2,8 \\
\hline Grecja & 6,2 & 7,4 & 10,4 & 15,5 & 19,4 & 22,2 & 19,7 & 16,8 & 14,9 \\
\hline Hiszpania & 9,4 & 15,5 & 15,8 & 16,2 & 18,4 & 18,2 & 16,1 & 14,7 & 12,9 \\
\hline Holandia & 1,1 & 1,9 & 2,3 & 2,4 & 2,6 & 3,6 & 3,0 & 2,6 & 2,3 \\
\hline Polska & 4,5 & 6,4 & 7,8 & 7,9 & 8,2 & 8,8 & 8,3 & 7,5 & 6,3 \\
\hline
\end{tabular}

Źródło: [http://ec.europa.eu/eurostat/].

Tabela 5. Stopa bezrobocia wśród kobiet w wieku 15-29 w wybranych krajach Unii Europejskiej w latach 2008-2016 (w \%)

\begin{tabular}{|l|r|r|r|r|r|r|r|r|r|}
\hline \multicolumn{1}{|c|}{ Wyszczególnienie } & \multicolumn{1}{c|}{2008} & \multicolumn{1}{c|}{2009} & \multicolumn{1}{c}{2010} & 2011 & 2012 & 2013 & 2014 & \multicolumn{1}{c|}{2015} & 2016 \\
\hline Unia Europejska & 11,8 & 14,3 & 15,5 & 16,2 & 17,4 & 17,8 & 16,8 & 15,1 & 13,9 \\
\hline Dania & 6,5 & 8,5 & 10,4 & 11,4 & 11,4 & 10,8 & 9,9 & 9,0 & 10,1 \\
\hline Grecja & 21,0 & 24,1 & 29,8 & 40,4 & 48,1 & 52,8 & 48,3 & 45,9 & 43,6 \\
\hline Hiszpania & 17,8 & 26,0 & 29,4 & 31,7 & 37,5 & 40,0 & 38,5 & 35,5 & 32,9 \\
\hline Holandia & 3,7 & 4,5 & 6,3 & 6,9 & 8,7 & 9,7 & 10,0 & 8,4 & 7,7 \\
\hline Polska & 13,6 & 15,0 & 17,7 & 19,4 & 20,9 & 21,0 & 17,6 & 13,9 & 11,9 \\
\hline
\end{tabular}

Źródło: [http://ec.europa.eu/eurostat/].

Tabela 6. Stopa NEET - bezrobotne kobiety w wieku 15-29 lat w wybranych krajach Unii Europejskiej w latach 2008-2016 (w \%)

\begin{tabular}{|l|c|r|r|r|r|r|r|r|r|}
\hline Wyszczególnienie & 2008 & 2009 & 2010 & 2011 & 2012 & 2013 & 2014 & 2015 & 2016 \\
\hline Unia Europejska & 4,9 & 5,8 & 6,2 & 6,5 & 6,9 & 7,1 & 6,6 & 6,1 & 5,6 \\
\hline Dania & 1,8 & 2,3 & 2,6 & 2,8 & 2,7 & 2,6 & 2,6 & 2,6 & 2,7 \\
\hline Grecja & 8,5 & 10,0 & 12,6 & 16,4 & 20,2 & 21,4 & 20,3 & 18,4 & 16,3 \\
\hline Hiszpania & 7,8 & 11,1 & 12,3 & 12,9 & 14,3 & 15,0 & 13,8 & 12,4 & 11,3 \\
\hline Holandia & 1,0 & 1,3 & 1,6 & 1,7 & 2,3 & 2,9 & 2,9 & 2,4 & 2,1 \\
\hline Polska & 4,4 & 5,2 & 5,9 & 6,6 & 7,2 & 7,6 & 6,7 & 5,3 & 4,5 \\
\hline
\end{tabular}

Źródło: [http://ec.europa.eu/eurostat/]. 
W roku 2013 podczas obrad szefów rządów UE postanowiono, że zostaną stworzone systemy „gwarancji dla młodzieży”, polegające na tym, że w ciągu 4 miesięcy od utraty pracy lub ukończenia szkoły młody człowiek powinien dostać dopasowaną do swojej sytuacji propozycję pracy, dalszej edukacji nauki, szkolenia zawodowego lub praktyki zawodowej [Szaban 2013, s. 266]. Przywódcy unijni ustanowili, iż na te cele w latach 2014-2020 należy wydać co najmniej 8 mld euro. Efektem tych działań jest spadek bezrobocia notowany od 2013 roku wśród osób należących do generacji NEET.

Niski poziom bezrobocia w Danii i Holandii wynika z realizacji tzw. flexicurity polityki rynku pracy, która łączy trzy elementy [Pancer-Cybulska 2014]:

1. Elastyczność zatrudniania i zwalniania pracowników (np. Praca w niepełnym wymiarze).

2. Wysokie bezpieczeństwo socjalne połączone z poszerzeniem kompetencji (wyrazem bezpieczeństwa socjalnego są wysokie nakłady na aktywne, jak i pasywne działania).

3. Aktywna polityka rynku pracy.

Kolejnym wskaźnikiem, na który należy zwrócić uwagę, jest wskaźnik dotyczący osób biernych zawodowo w odniesieniu do całkowitej stopy NEET.

Tabela 7. Osoby bierne zawodowo w wieku 15-29 lat w ogólnej liczbie osób (populacji) w wybranych krajach Unii Europejskiej w latach 2008-2016 (w \%)

\begin{tabular}{|l|c|c|c|c|c|c|c|c|c|}
\hline Wyszczególnienie & 2008 & 2009 & 2010 & 2011 & 2012 & 2013 & 2014 & 2015 & 2016 \\
\hline Unia Europejska & 2 & 2,1 & 1,8 & 1,7 & 1,7 & 2,0 & 2,1 & 2,3 & 2,4 \\
\hline Dania & 1,3 & 1,5 & 1,9 & 2,2 & 2,3 & 2,3 & 2,1 & 2,4 & 3,0 \\
\hline Grecja & 3 & 2,7 & 3,1 & 3,1 & 3,2 & 3,0 & 3,4 & 3,4 & 3,4 \\
\hline Hiszpania & 1,8 & 1,8 & 1,5 & 1,4 & 1,3 & 1,4 & 1,3 & 1,3 & 1,6 \\
\hline Holandia & 1,6 & 1,5 & 1,6 & 1,6 & 1,7 & 1,8 & 2,0 & 2,0 & 2,3 \\
\hline Polska & 0,7 & 0,6 & 0,5 & 0,4 & 0,4 & 0,4 & 0,4 & 0,4 & 0,4 \\
\hline
\end{tabular}

Źródło: [http://ec.europa.eu/eurostat/].

Tabela 8. Osoby bierne zawodowo należące do NEET w wieku 15-29 lat w wybranych krajach Unii Europejskiej w latach 2008-2016 (w \%)

\begin{tabular}{|l|c|c|c|c|c|c|c|c|c|}
\hline Wyszczególnienie & 2008 & 2009 & 2010 & 2011 & 2012 & 2013 & 2014 & 2015 & 2016 \\
\hline Unia Europejska & 7,7 & 7,8 & 7,9 & 8,0 & 7,9 & 7,8 & 7,8 & 7,9 & 8,0 \\
\hline Dania & 3,1 & 3,4 & 3,8 & 4,4 & 5,0 & 4,7 & 4,4 & 4,9 & 4,7 \\
\hline Grecja & 7,5 & 7,2 & 7,2 & 7,1 & 7,0 & 6,7 & 6,7 & 6,5 & 6,6 \\
\hline Hiszpania & 6,6 & 6,5 & 5,9 & 6,0 & 5,9 & 5,9 & 5,8 & 5,9 & 6,0 \\
\hline Holandia & 3,6 & 3,6 & 3,8 & 3,8 & 4,0 & 4,3 & 4,7 & 4,2 & 4,1 \\
\hline Polska & 8,3 & 8,2 & 7,8 & 7,9 & 8,0 & 8,0 & 8,0 & 8,2 & 8,4 \\
\hline
\end{tabular}

Źródło: [http://ec.europa.eu/eurostat/]. 
Analizując dane w tabelach 7 i 8, można stwierdzić, że wskaźnik dotyczący osób biernych zawodowo wśród generacji NEET osiągnął większe wartości w porównaniu ze wskaźnikiem dotyczącym osób biernych zawodowo wśród populacji w wieku $15-29$.

Z danych dotyczących bierności zawodowej wśród mężczyzn należących do grupy NEET w wieku 15-29 lat, udostępnionych w bazie Eurostat w roku 2016, wynika, że wartość wskaźnika kształtowała się na podobnym poziomie we wszystkich badanych krajach - Dania (4,4\%), Holandia (3,4\%), Hiszpania (4,6\%), Grecja (4,9\%) i Polska (4,4\%). Wartości wskaźnika dotyczącego bierności zawodowej wśród mężczyzn NEET w 2016 roku kształtowała się poniżej średniej wartości dla całej Unii Europejskiej, która wyniosła 5,3\%.

Z kolei wskaźnik dotyczący bierności zawodowej kobiet należących do grupy NEET w wieku 15-29 lat w 2016 roku kształtował się na dużo wyższym poziomie niż w przypadku mężczyzn i wyniósł: Dania (5\%), Grecja (8,5\%), Hiszpania $(7,4 \%)$, Holandia (4,8\%), Polska (12,6\%). Średnia wartość wskaźnika dla całej Unii Europejskiej wyniosła w 2016 roku 10,7\%.

Bierność zawodowa wśród młodych osób kojarzy się z pewną niezaradnością życiową, ale nie tylko one same są za to odpowiedzialne, odpowiadają za to również uwarunkowania współczesnego rynku pracy i system edukacji. Co ciekawe, osobom z wyższym wykształceniem jest coraz trudniej znaleźć pracę zgodną z posiadanymi kwalifikacjami. W Hiszpanii w roku 2016 3,4\% osób generacji NEET w wieku 15-29 miało wyższe wykształcenie, w Grecji 5,8\%, w Danii 1,2\%. W Holandii to wartość $0,8 \%$, natomiast w Polsce 2,1\%.

Analizując dane w tab. 9, można stwierdzić, że najniższy wskaźnik zatrudnienia wśród osób w wieku 15-29 lat w badanym okresie występuje w Grecji i Hiszpanii, najwyższy w Holandii i Danii.

Tabela 9. Wskaźnik zatrudnienia wśród osób w wieku 15-29 lat w wybranych krajach UE ze względu na kraj urodzenia (w \%)

\begin{tabular}{|l|c|c|c|c|c|c|c|c|c|}
\hline \multicolumn{1}{|c|}{ Wyszczególnienie } & 2008 & 2009 & 2010 & 2011 & 2012 & 2013 & 2014 & 2015 & 2016 \\
\hline Unia Europejska & 50,7 & 48,4 & 47,4 & 47,0 & 46,3 & 45,9 & 46,5 & 47,3 & 48,3 \\
\hline Dania & 73,3 & 68,3 & 64,1 & 63,5 & 61,0 & 60,5 & 60,1 & 61,8 & 64,0 \\
\hline Grecja & 41,7 & 41,0 & 37,7 & 32,0 & 28,0 & 25,0 & 26,4 & 27,2 & 27,9 \\
\hline Hiszpania & 51,4 & 43,9 & 40,4 & 38,1 & 34,2 & 32,6 & 32,8 & 33,0 & 33,8 \\
\hline Holandia & 77,5 & 76,1 & 71,6 & 70,6 & 70,1 & 68,9 & 67,7 & 69,6 & 69,6 \\
\hline Polska & 45,0 & 44,7 & 43,9 & 43,4 & 43,2 & 42,9 & 44,4 & 45,0 & 47,7 \\
\hline
\end{tabular}

Źródło: [http://ec.europa.eu/eurostat/].

Wyższy poziom zatrudnienia w Danii i Holandii związany jest z przyjętą polityką rynku pracy, tzw. flexicurity, która została opisana wcześniej. 


\section{Ekonomiczne i społeczne koszty wynikające $z$ istnienia generacji NEET}

Koszty ekonomiczne związane z wystąpieniem zjawiska NEET można podzielić na koszty bezpośrednie i koszty pośrednie. Koszty bezpośrednie obejmują dochody finansów publicznych, czyli np. zasiłki dla bezrobotnych. Koszty pośrednie obejmują koszty utraconych zasobów, np. niezapłacone podatki, utracone dochody. Koszty pośrednie są trudno mierzalne z uwagi na brak lub trudność w dostępie do nich.

Koszty finansów publicznych określa się jako różnicę między dochodem finansów publicznych otrzymywanym przez NEET a grupę nienależącą do NEET. Z kolei koszty zasobów oblicza się jako różnicę między dochodem zasobów generowanych przez NEET a grupę nienależącą do NEET.

$\mathrm{Na}$ postawie raportu NEETS Young people not in employment, education or training: Characteristics, costs and policy responses in Europe, opublikowanego przez Eurofond w 2012 roku, oszacowano koszty zjawiska NEET (koszty finansów publicznych i koszty zasobów) w 2008 i 2011 roku [Eurofond 2012]. Z przywołanego raportu wynika, że w 2008 roku w Danii koszt całkowity (koszt finansów publicznych + koszty zasobów) wyniósł 778693412 euro, w Holandii 3095213588 euro, w Polsce 5376259463 euro, natomiast w Grecji 4043401502 euro, w Hiszpanii 10794369211 euro. W 2011 roku koszt całkowity wyniósł w Danii 1287222442 euro, w Holandii 3957261493 euro, w Polsce 7535945953 euro, w Grecji 706560979 euro, natomiast w Hiszpanii 15735159614 euro.

We wszystkich pięciu badanych krajach straty (koszty) ekonomiczne z tytułu nieuczestniczenia młodych ludzi (NEET) w rynku pracy wzrosły w roku $2011 \mathrm{w}$ porównaniu z rokiem 2008. Ponadto w Grecji w 2011 roku koszty NEET przekroczyły 3\% PKB. Najniższą wielkość kosztów NEET wyrażoną w udziale PKB w 2011 roku osiągnęła Dania (0,54 \% PKB).

Oprócz kosztów ekonomicznych występują również koszty społeczne i osobiste związane z przynależnością osób do NEET. Problem pokolenia NEET jest bardzo istotny, bo niesie za sobą wiele negatywnych konsekwencji społecznych, takich jak: niezadowolenie, niepewne i nieadekwatne przyszłe zatrudnienia, popełniane przestępstwa przez młodzież oraz problemy związane ze zdrowiem psychicznym i fizycznym [Rogozińska-Pawełczyk 2014, s. 119]. Osoby pozostające bez pracy łatwo tracą poczucie własnej wartości, pewności siebie, czują się odizolowane od społeczeństwa. Odczucia te mogą prowadzić do rozczarowania, a w efekcie do frustracji i poczucia braku wpływu na własne życie. Wyniki badania Youth Index 2015 (tab. 10), przeprowadzonego przez brytyjską organizację Princes's Trust, wskazują, że młodzież należąca do generacji NEET ma mniejsze poczucie wiary w siebie, większe poczucie braku motywacji do działania i wpływu na własne życie oraz trudności w znalezieniu pracy i zdobywaniu nowych umiejętności w stosunku porównaniu z osobami nienależącymi do generacji NEET. 
Tabela 10. Negatywne emocje i odczucia osób należących do generacji NEET i nienależących do generacji NEET (w \%)

\begin{tabular}{|l|c|c|}
\hline \multicolumn{1}{|c|}{ Wyszczególnienie } & NEET & No NEET \\
\hline Brak poczucia wiary w siebie & 59 & 50 \\
\hline Brak poczucia motywacji & 60 & 48 \\
\hline Brak poczucia wpływu na własne życie & 45 & 32 \\
\hline Brak wiary w osiągnięcie sukcesu & 47 & 31 \\
\hline Trudność w znalezieniu pracy & 33 & 15 \\
\hline Trudności w nauczeniu się nowych umiejętności & 19 & 10 \\
\hline
\end{tabular}

Źródło: [www.princes-trust.org.uk].

\section{Zakończenie}

W związku ze zmianami demograficznymi zachodzącymi w Unii Europejskiej, tzn. starzeniem się ludności i niskim poziomem dzietności, niewątpliwie struktura ludności według wieku w Unii Europejskiej ulegnie radykalnej zmianie. Nie musi to oznaczać, że problem związany z wysokim bezrobociem wśród młodych ludzi, a szczególnie wśród osób należących do generacji NEET, ulegnie zmniejszeniu lub całkowicie zniknie. Oznacza to, że wzrost liczebności starszych pracowników nie zostanie wyrównany wzrostem liczebności młodych, aktywnych zawodowo pracowników.

Czynnikiem, który zaostrzył problem bezrobocia wśród młodych ludzi, był kryzys gospodarczy z lat 2007-2010, który nie oszczędził tej grupy ludzi na rynku pracy. Choć sytuacja obecnie się poprawiła, to i tak stopa NEET w grupie wiekowej 15-29 i ogólna stopa bezrobocia młodzieży w wieku 15-29 w 2016 roku osiągnęła wartość ponad $14 \%$.

Bardzo dużym problemem wśród osób należących do generacji NEET w wieku 15-29 jest ich bierność zawodowa. Niepokojącym zjawiskiem jest również wysoka bierność zawodowa wśród kobiet (NEET), średnia wartość dla UE w roku 2016 osiągnęła poziom 10,7\%, a w przypadku mężczyzn (NEET) jest to poziom 5,3\%. Z negatywnym zjawiskiem NEET wiążą się również wysokie koszty ekonomiczne, we wszystkich pięciu analizowanych krajach członkowskich straty (koszty) ekonomiczne z tytułu nieuczestniczenia młodych ludzi (NEET) w rynku pracy sukcesywnie wzrastają. Analiza struktury młodych osób należących do generacji NEET jednoznacznie wskazuje, że należy stworzyć młodym ludziom możliwości działania, motywować i tym samym uchronić przed bezczynnością. 


\section{Literatura}

Eurofond, 2012, NEETS Young people not in employment, education or training: Characteristics, costs and policy responses in Europe, https://www.eurofound.europa.eu/ (21.10.2012).

Eurostat, 2018a, Estimated average age of young people leaving the parental household by sex, http:// ec.europa.eu/eurostat/data/database (16.04.2018).

Eurostat, 2018b, Inactive population not seeking employment by sex, age and main reason, http://ec.europa.eu/eurostat/data/database (5.05.2018).

Eurostat, 2018c, Youth employment rate by sex, age and country of birth, http://ec.europa.eu/eurostat/ data/database (7.04.2018).

Eurostat, 2018d, Young people neither in employment nor in education and training by sex, age and labour status (NEET rates), http://ec.europa.eu/eurostat/data/database (14.04.2018).

Eurostat, 2018e, Young people neither in employment nor in education and training by sex \% population aged 15 to 29, http://ec.europa.eu/eurostat/data/database (29.04.2018).

Eurostat, 2018f, Youth unemployment rate by sex, age and country of birth, http://ec.europa.eu/eurostat/ data/database (30.04.2018).

Gałaj W., 2014, Pokolenie Z na rynku pracy, [w:] Pokolenia na rynku pracy, red. A. Rogozińska-Pawełczyk, Wydawnictwo Uniwersytetu Łódzkiego, Łódź, s. 85.

http://ec.europa.eu/eurostat.

https://www.eurofound.europa.eu.

Kubin T., 2016, Kryzys gospodarczy w Hiszpanii, przyczyny, przejawy, nastęstwa, Zeszyty Naukowe Uniwersytetu Ekonomicznego w Katowicach, nr 287, Katowice.

Malo M.A., Moreno A., 2018, Introduction, [w:] European Youth Labour Markets: Problems and Polices, eds. M.A. Malo, A. Moreno, Springer International Publishing AG, Switzerland, s. 1, https:// books.google.pl (13.07.2018).

Olofsson J., Panican A., 2018, Apprenticeship training in upper secondary school, movies and possibilities from a Swedish and European perspective, [w:] European Youth Labour Markets: Problems and Polices, eds. M.A. Malo, A. Moreno, Springer International Publishing AG, Switzerland, s. 80, https://books.google.pl (13.07.2018).

Osiecka K., 2009, Pokolenie Y a zarzadzanie kadrami w przedsiębiorstwie, Zeszyty Studenckie Uniwersytetu Ekonomicznego w Gdańsku, nr 4, Gdańsk, s. 358.

Pancer-Cybulska E., 2014, Aktywna polityka rynku pracy w krajach Unii Europejskiej w okresie kryzysu, Studia Ekonomiczne, t. 166, Wydawnictwo Uniwersytetu Ekonomicznego w Katowicach, Katowice, s. 43-57.

Princes's Trust, 2015, Youth Index 2015, https://www.princes-trust.org.uk/

Rogozińska-Pawełczyk A., 2014, Pokolenie NEET czyli młodzież bez pracy, nauki i szkolenia: charakterystyka, koszty i rozwiąania polityczne na przykładzie Europy, [w:] Pokolenia na rynku pracy, red. A. Rogozińska-Pawełczyk, Wydawnictwo Uniwersytetu Łódzkiego, Łódź, s. 112-114.

Suwa M., 2014, Pokolenie Y na polskim rynku pracy, [w:] Pokolenia na rynku pracy, red. A. Rogozińska-Pawełczyk, Wydawnictwo Uniwersytetu Łódzkiego, Łódź, s. 66-67.

Szaban J., 2013, Rynek pracy w Polsce i w Unii Europejskiej, Difin, Warszawa.

www.princes-trust.org.uk 